\title{
The Ceramics of Singkawang: Dayak Kanayatn's Cultural Perceptions in Kalimantan Barat
}

\author{
Iwan Pranoto', Vitta Diana Siahaan ${ }^{2}$, Triyanto ${ }^{3}$, Tjetjep Rohendi Rohidi ${ }^{3}$ \\ Pendidikan SENDRATASIK, FKIP Universitas Palangkaraya ${ }^{1}$ \\ 'iwanpranotoart@gmail.com
}

This study examines the cultural perceptions of Dayak Kanayatn community on Singkawang ceramics. The scope of the problem includes, aesthetic, community perception, and ceramics function based on cultural perception. The research location was in Sebetuk, Antan Rayan Village, Ngabang District, Landak Regency, Kalimantan Barat. A qualitative design in the form of case studies was used. Data were gathered using observation, interviews, and documents. The findings of this study overall proved that Singkawang ceramics owned by Dayak Kanayatn community influenced by Chinese culture as seen on boko'o, siam, jampa, tajau, karokot, siton, twakag ba'butuh, banyanyi, karere, balangkas, oncok tabu, plate variants, tetek ijo. Dayak Kanayatn community believe on ceramics as an incarnation of the ancestors and referred as a tangah symbolized by the variety of decoration and form. The ceramics are used by the community as media for several activities as well on law regulations and are considered as a link between humans and ancestral spirits of the Dayak Kanayatn tribe.

Keyword: perception, ceramics, dayak kanayatn

Proses Review : 1 - 28 Januari 2020, Dinyatakan Lolos: 10 Februari 2020 


\section{PRELIMINARY}

The development of a culture in a community is caused by the increase of human resources, which is related to the daily life as outlined in a work of art. As stated by (Koentjaraningrat 2011: 165) that culture is the ideas, activities, and objects created by humans. Art is a human creation starts from the idea of human thought. Art that develops in society gives an impact especially in communication. As stated by (Wastap 2010: 37-38) that communication through art has the aim of conveying aesthetic experiences, whether through dialogue, drama, music, dance or appearance. The communication that occurs through art can influence people's views in the form of local cultural perceptions.

The emergence of community perceptions of art, one of which occurred in the Dayak Kanayatn community in perceiving Singkawang ceramics that had an aesthetic, daily use impact. As stated by (Dodo 2016: 124) that the Dayak Kanayatn use handicraft works for ritual purposes as well as for profane needs. This happened to the ceramics owned by the Dayak Kanayatn community in their daily activities related to mere function and ritual.

In everyday life the Dayak Kanayatn, Singkawang ceramics are cultural product that is very close to their social life including religious interests or practical needs. As (Dodo 2016: 124), Dayak Kanayatn traditional ceremonies such as Liatn (treatment), Babalak (circumcision), traditional marriages, karusakatn (death) rituals, ascending dango rituals, customary law, cannot be separated from craft art. The handicraft products used by the Dayak Kanayatn are ceramics considered sacred, and have certain meanings to rule their social life, in the form of Dayak Kanayatn customary law.

Ceramic Singkawang which is present at the Dayak Kanayatn community is the one of the communication media. As stated by (Iskandar 2004: 121), that there are several parts to cultural products in communicating to the community, namely: (a) symbols and meanings; (b) norms; and (c) history. Ceramics as a work of art is a produce cultural perceptions in society. The perception that developed in the Dayak Kanayatn community towards ceramics was inseparable from the cultural elements of the community. As stated by Richard E. Porter (Mulyana 2010: 214) that there are six cultural elements that influence human perception of art works, namely, beliefs, world views, social organization, human nature, activity orientation, and perceptions about themselves and others. The following is a picture of the cultural perceptions that developed in the ceramic Singkawang art work that existed in the Dayak Kanayatn community group.

Cultural perceptions of community on a work of art can change every situation that develops in society, such as the

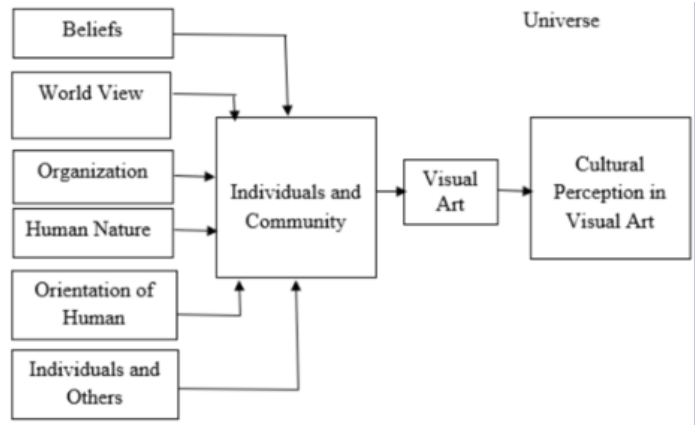

Figure 1. Cultural Perception in Visual Art (modified by the writer) Source: Mulyana (2010: 214)

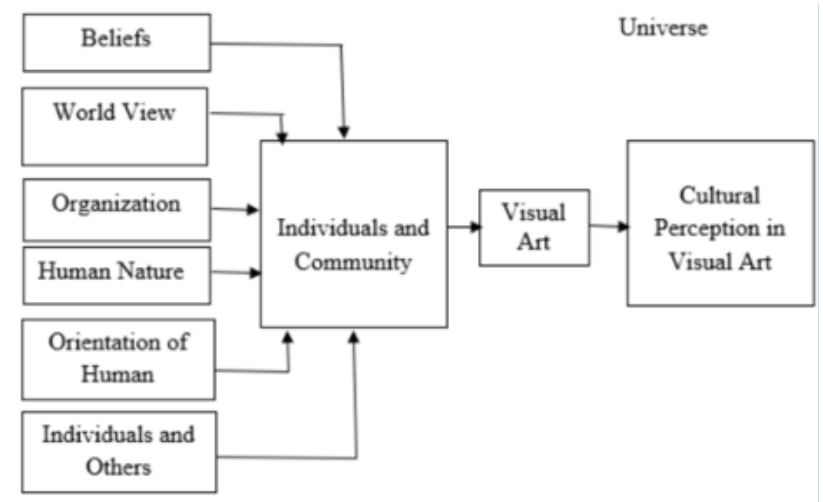

Figure 2. The Art Elements and Principal of Visual Art Source: Ocvirk (1992:33)

relationship between art and beliefs, world view, organization, human nature, orientation of human activities, individuals and others. The result of a perception in society is a thought that can be seen verbally and in writing. It was in the form of sections that included elements of visual arts. As stated by Ocvirk (1992: 73) that the art elements are consist of line, shape, value, texture, and color. The principles of organization balance, proportion, dominance, ownership, economy and unity. Art elements contained in a work of art have values in the form of balance, proportion, shape, dominant, economical, and variations, so that it becomes a unity. Likewise, ceramic Singkawang are found in the Dayak Kanayatn community in Kalimantan Barat. The following is a concept description to analyze the aesthetic value of works of art.

From the explanation, the interrelationship between the forms of art and craft which includes lines, shapes, fields and spaces, textures, colors, and value. The existence of a harmonious form becomes a unity ceramics Singkawang in the Dayak community has an influence on the function of ceramics. As stated by (Syuhendri 2008: 10-11) that the development of art, one of which is ceramics in a group of people gives an influence on a new perspective in enjoying, presenting, and functioning. Another opinion by (Wasudewa 2014: 2) that handicraft is an art object that is processed using skillful hands of different forms and functions that are useful to meet human needs. Function based on the interests of the community is inseparable from the 


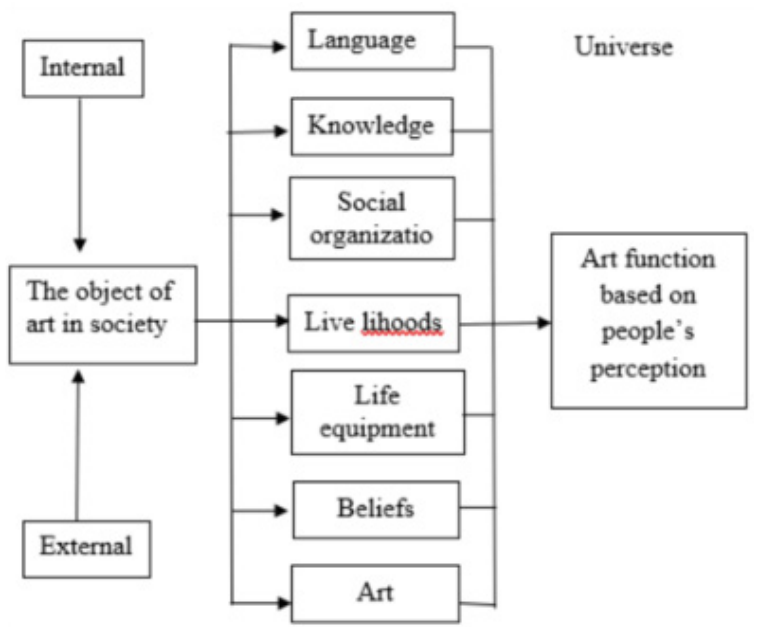

Figure 3. The Function of Art in Cultural Perception (Modified by the writer)

Source: Koentjaraningrat (1986: 203-204)

form including size, as well as aesthetic value. Thus, the craft has various types of forms based on their functions, related to cultural elements of the Dayak Kanayatn community. The following is the function of ceramic Singkawang handicrafts that have an impact on the Dayak Kanayatn community.

The function of ceramic Singkawang in the Dayak Kanayatn community has influence the religious system, beliefs, livelihoods, social organization, knowledge and language. This has led to a perception of culture in the community that is inseparable from the cultural elements of the Dayak Kanayatn community when using ceramic Singkawang.

The explanation underlying this research that there is a cultural process influenced by the others culture enters the Dayak Kanayatn community through ceramic Singkawang so as to create a culture for the local community in upholding the social values of the community, in the form of cultural perceptions related to the life of the Dayak Kanayatn. This research is to discuss the development of cultural perceptions in the community as seen from the variety of ceramics and the aesthetic forms of ceramics affect the functioning of Singkawang ceramics. The research location is located in Sebetuk, Antan Rayan Village, Ngabang, Landak regency, this area is a settlement of Dayak Kanayatn community.

\section{RESEARCH METHOD}

This research used an interdisciplinary approach supported by several scientific disciplines such as social, cultural, aesthetic, and communication. A qualitative design in the form of case studies was used. Data were gathered using observation, interviews, and documents. The research process is carried out by taking data in accordance with the formulation of the problem and supporting theories in the study. Field study is to find phenomena to be felt directly by researchers by writing, recording, asking, collecting the documents, observing and feeling.

To ensure information in the form of data obtained from the field, data testing is needed, or known as data validity. As stated by (Rohidi 2011: 218) that validity or often called trustworthiness is a reliable and reasonable data information. To achieve a reliable data, triangulation of data is needed, namely: (a) data triangulation, (b) triangulation of sources and (c) triangulation method. The data presentation stage refers to the sources obtained while in the field, and the data that has answered the problem formulation. In the conclusions and data verification section, a conclusion is drawn based on the data obtained which is then reduced and presented based on the problem.

The Variety of Ceramics and Aesthetic Analysis of Ceramics Singkawang in the Dayak Kanayatn Communities.

Ceramic Singkawang that are owned by the Dayak Kanayatn community in Kalimantan Barat have an aesthetic form that cannot be separated from the visual arts elements. This makes ceramics owned by the community in this area can be seen from aesthetic visuals. There are 238 types of ceramics owned by the community in this area. There are similarities in shape and size with ceramics so that to represent all ceramics, 20 types of ceramics are chosen, including: jars, plates and bowls. Following are the types of ceramics that were analyzed visually, along with the name of ceramics.

Ceramics owned by the Dayak Kanayatn community in Sebetuk have various names, such as jars of boko'o, siam, jampa, tajau, karokot, siton, twakag ba'butuh, banyanyi and karere. These types of ceramic have a large size and each surface is covered with glaze, which is then some ceramics decorated with dragon motifs and some are plain without ornamental variety. Ceramic balangkas and oncok taboo are type of plate associated with natural and floral motifs. These ceramics have various sizes and basic circular shape in order to make the flat surface of this ceramic look clearer and there is a hollow inside the plate. The type of plain bowls and tetek ijo have a wall shape that is higher than the surface and there is a base.

Singkawang Ceramics owned by the Dayak Kanayatn community have a smooth surface and covered with glaze made by a high temperature of $1200^{\circ} \mathrm{C}$. As stated by Yudhantara (in Rahmawati 2011: 2) that clay which is burned at $900^{\circ} \mathrm{C}-1100^{\circ} \mathrm{C}$ is called Earthenware, a temperature of $1200^{\circ} \mathrm{C}$ is called stoneware, and a temperature of $1260^{\circ}$ $\mathrm{C}$ is called porcelain. Singkawang Ceramics, which are owned by the Dayak Kanayatn community are ceramics that have good quality with a simple shape.

Each of the ceramics works has a philosophical value found in the elements of visual art. As stated by (Pawistana 2014: 1-2) that there are philosophical symbols and values in traditional craft art works by bringing up traditional el- 
Table: 1. Ceramic Singkawang Form in Dayak Kanayatn Community. Source: Iwan Pranoto (April 2017)

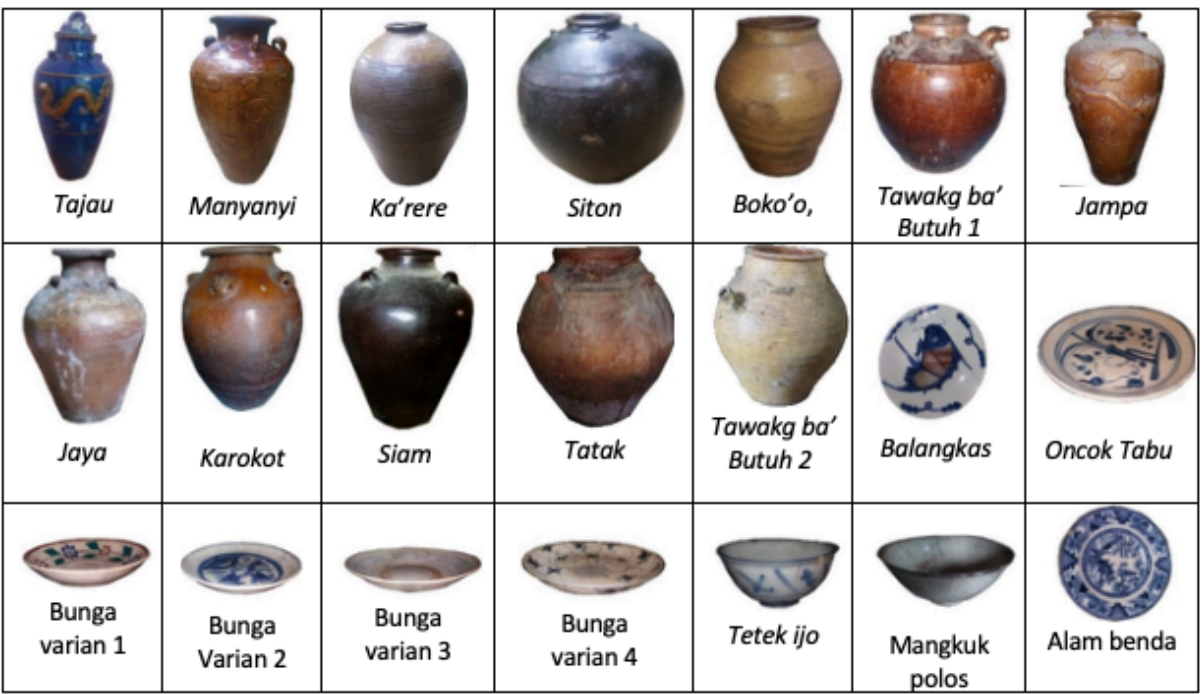

Table 2. Visual art elements (Source:: iwan pranoto 2019)

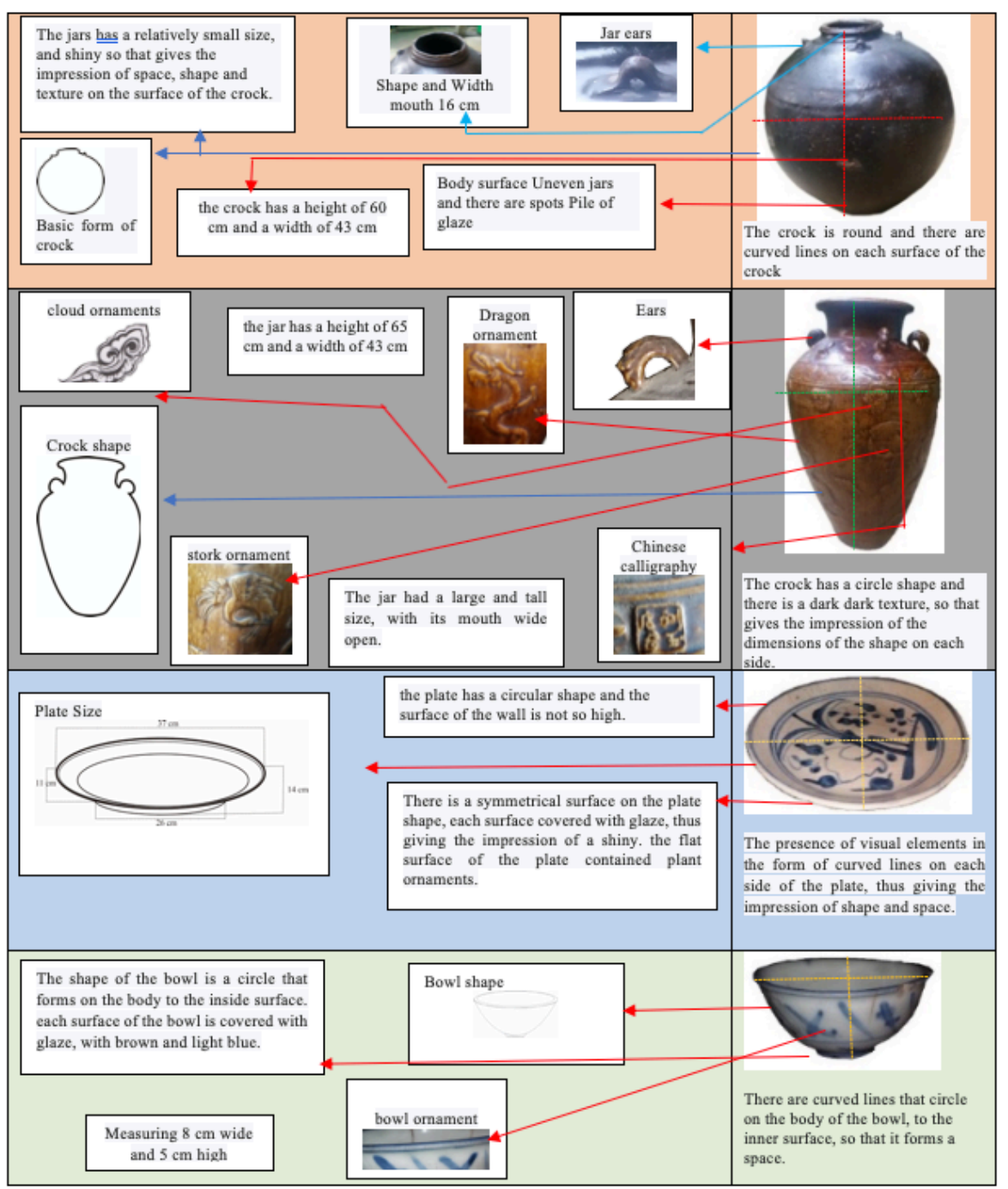


Table 3. The meaning of Chinese Singkawang ceramics (Iwan Pranoto, 2019)

\begin{tabular}{|c|c|}
\hline Picture & Meaning Ceramics \\
\hline & $\begin{array}{l}\text { The shapes on the jars, bowls and ceramic plates are considered as incarnations of } \\
\text { the lives of deceased humans such as the Dayak commander, or magic person. } \\
\text { This was interpreted by the Dayak Kanayatn community that ceramics are the } \\
\text { origin of human life, namely the land and will return to the ground. }\end{array}$ \\
\hline & $\begin{array}{l}\text { Dragon ornaments are considered as symbols of ancestors who are always } \\
\text { present in the life of the Dayak Kanayatn community. Dragons are considered as } \\
\text { creatures that can convey human messages to the creator. }\end{array}$ \\
\hline & $\begin{array}{l}\text { Plant ornaments are considered a symbol of Kalimantan abundant natural } \\
\text { fertility, in order to support the Dayak Kanayatn community. }\end{array}$ \\
\hline & $\begin{array}{l}\text { Ears on the crock symbolize that humans in speaking the words can always be } \\
\text { heard by the ancestors, so that the Dayak Kanayatn community must speak good } \\
\text { and polite to fellow human beings. }\end{array}$ \\
\hline & $\begin{array}{l}\text { The ornaments of the cloud is symbolized as a source of fertility on the ground by } \\
\text { reducing rain, so that the water obtained can feed everything on earth. }\end{array}$ \\
\hline & $\begin{array}{l}\text { The stork symbolizes the perseverance of the Dayak Kanayatn in working hard } \\
\text { to fulfill their daily lives. }\end{array}$ \\
\hline
\end{tabular}

ements in each region. Another opinion (Triyanto 2016: $5)$, that the emergence of a feeling of beauty through the media lines, colors, textures, fields, volume and space or in other words through learning in the field of ceramic. The appearance of the elements of visual art in a ceramic craft work an aesthetic sense. The following is a picture of aesthetic visual analysis of ceramic Singkawang in the Dayak Kanayatn community in Sebetuk.

Based on the picture above, Singkawang ceramics that are owned by the Dayak Kanayatn community have a simple form, and in each part this ceramic has its own characteristics. This can be seen from the color, size and shape of the entire ceramic. As stated by (Arimbawa 2011: 172) that ceramics in several regions of Indonesia have characteristics both aesthetically and in quality. From the opinions expressed that Singkawang ceramics have a simple form, smooth and rough surface, and mystical. This is found in the visual art elements found in ceramics the perception of the Dayak Kanayatn community. In this section there is a visual analysis of Singkawang Chinese ceramics which is analyzed to represent several other ceramics. That is because there are similarities in shape, color, decoration, and size of ceramics consisting of jars, plates and bowls.

The existence of visual elements in ceramics which include the jars, bowls and plates so as to give the impression in the form of meanings associated with the Dayak Kanayatn community in Kalimantan Barat. It covers shapes, decoration, colors, each of these parts giving an impression to the Dayak Kanayatn community to organize a better social life between each other and nature. The following is the mean- ing found in Singkawang Chinese ceramics in the Dayak Kanayatn community in Kalimantan Barat.

\section{Dayak Kanayatn's Perception of Ceramic Singkawang} The Dayak Kanayatn community in Antan Rayan village has different perceptions of Singkawang ceramics that enter to the area. It is based on experience, selective, evaluative, conjecture, and contextual. The perception that arises in this community gives influence to other community groups. This was based on the thoughts of several community leaders namely, traditional leaders, the community, religion, local government, and the general public.

The perception of traditional leaders through Singkawang ceramics owned by the Dayak Kanayatn community in this area contains the values of customs, sacred and social messages in the life of the local community, such as violations of norms namely, fighting, infidelity, murder, theft, theft between groups or ethnicity given customary payment penalties by using ceramics. As stated by (Iskandar 2004: 121) that there are regulations to reconcile ethnic warfare between Dayak and Madura tribes, through the customary legal system. Customary regulations relating to social violations can be resolved by holding a consultation process and a peace process using ceramics.

The perception of community including several community leaders of teachers and government that Singkawang ceramics are a local culture and can be used as formal, informal and informal learning material. As stated by (Triyanto 2015: 1) that there is inheritance as an educational process in the Mayong Lor community in creating ceramic art. 
From the opinion that has been revealed that there is a process of inheritance in the form of social messages which is owned by the Dayak Kanayatn community. The process of inheritance of ceramic has benefits in the daily life of local people in the formation of characters by verbally in the form of social messages on ceramics, which are carried from generation to generation, such as protecting the natural surroundings, as well as behaving to the community. As stated by (Rohidi 2014: 1) that the application of wayang as a medium of learning based on local culture, in order to rise local culture. From the opinions expressed that the local culture owned by community groups, especially Singkawang ceramics owned by the Dayak Kanayatn community is used as a source of learning local culture, thus giving certain messages in people's lives.

As stated by (Triyanto 2014: 39) that culture-based arts education has meaning in every educational program designed to place culture, which contains systems of knowledge, values, and beliefs that are owned and used as guidelines by a community group, be a source, spirit, or breath that animates both philosophical and implementation levels. From the opinion that was put forward that art products, especially Singkawang ceramics found in the Dayak Kanayatn community, were made by several community leaders as the formation of human character in social life including customary law regulations to prevent illegal acts, the existence of regional boundary regulations, sanctions for those fighting, theft, infidelity, harming others, and pitting communities.

The perception of religious leaders views that ceramics are only items of cultural heritage from ancestors. It is in conflict with the Christian view that developed in this area with the view of the Bible (Leviticus 26, verse 1) saying thus "do not make idols for you, and idols or statues, do not build for yourself also carved stones, do not place them in your country to bow down to worship him “. The Dayak Kanayatn community who embraced Christianity considered the ceramics used in traditional religious rituals to be an act of worshiping idols. The application of ceramics by religious leaders is limited to the media, but the existence of ceramics can still be accepted as the cultural identity of the region. As stated by (Suryani 2013: 4) that through the media using art goods to achieve the communication process and develop in the community. Dayak Kanayatn who have believed in Christian have a perception that ceramics are conflicting in religious activities, namely ceramics used to offer ancestors to the local community, ceramics are only a media item for local cultural identity.

The perception of Singkawang ceramics is based on the views of government figures that ceramics are cultural objects that contain social messages and are considered to have a sacred element. Ceramics can reject a catastrophic accident that occurs, so that the accident area will not ask for victims, by giving offerings of ceramic. As stated by (Adhyatman and Ridho 1984: 16) that some jars used by the Dayak community for death ceremonies are like in East Kalimantan, the jars are worshiped by Dayak Ngaju as the graves of their chiefs in the past. From the opinion stated that Dayak Kanayatn community also conducts ceremonial activities to give ceramics items which are considered sacred.

The general perception is based on the ownership of ceramics that ceramics are considered sacred items and are believed. As stated by (Adhyatman and Ridho 1984: 16) that in West Kalimantan the urn with two vertical dragons facing pearl motifs is often used as a grave container, placed on a pole so that it emits sound when blown by the wind and is called singing dragon. From the opinion expressed by Dayak Kanayatn people consider the incarnation of ceramics from the ancestors to look after the household in collecting food sources for survival, therefore ceramics have a special treatment by filling rice in ceramic jars, this activity is called the customary tradition of the local community.

The existence of Singkawang ceramics for the Dayak Kanayatn community is a local cultural identity, in the form of customary law regulations, traditional belief ceremonies, and the application of ceramics as formal, informal and informal learning items. This was expressed through communication so that the community was perceived by linking the local culture based on several community leaders who were considered capable of having an influence on society in general. As stated by (Regar 2014: 2 ) that the communication using a symbol as a medium or channel of human thought to objects or objects around. From the opinions expressed that the Dayak Kanayatn community had expressed perceptions and communication to deliver social messages so as not to violate the prevailing norms, through the Singkawang ceramics.

\section{The Function of Ceramics Singkawang Based on Per- ception of Dayak Kanayatn Community}

Singkawang Ceramics owned by the Dayak Kanayatn community have different functions that create different perceptions. Perceptions that arise in society are influenced by the culture that develops in society, such as language, knowledge, social organization, living equipment, livelihoods, religious facilities, and the arts. The following is the function of Singkawang ceramics based on the perception of the Dayak Kanayatn community.

The function of ceramics is to associate the values of trust with ceramic as an ancestral inheritance that contains sacred values. This is evidenced by several actions of the community who believe that ceramics used to store food and drink, are considered to be able to bring fortune and keep the contents of the jar in spirit. The types of ceramics are jars, siam, jampa, manyanyi, tatak, karokot, jaya,. As stated by Laksana (2013: 2) that there are handicrafts made 


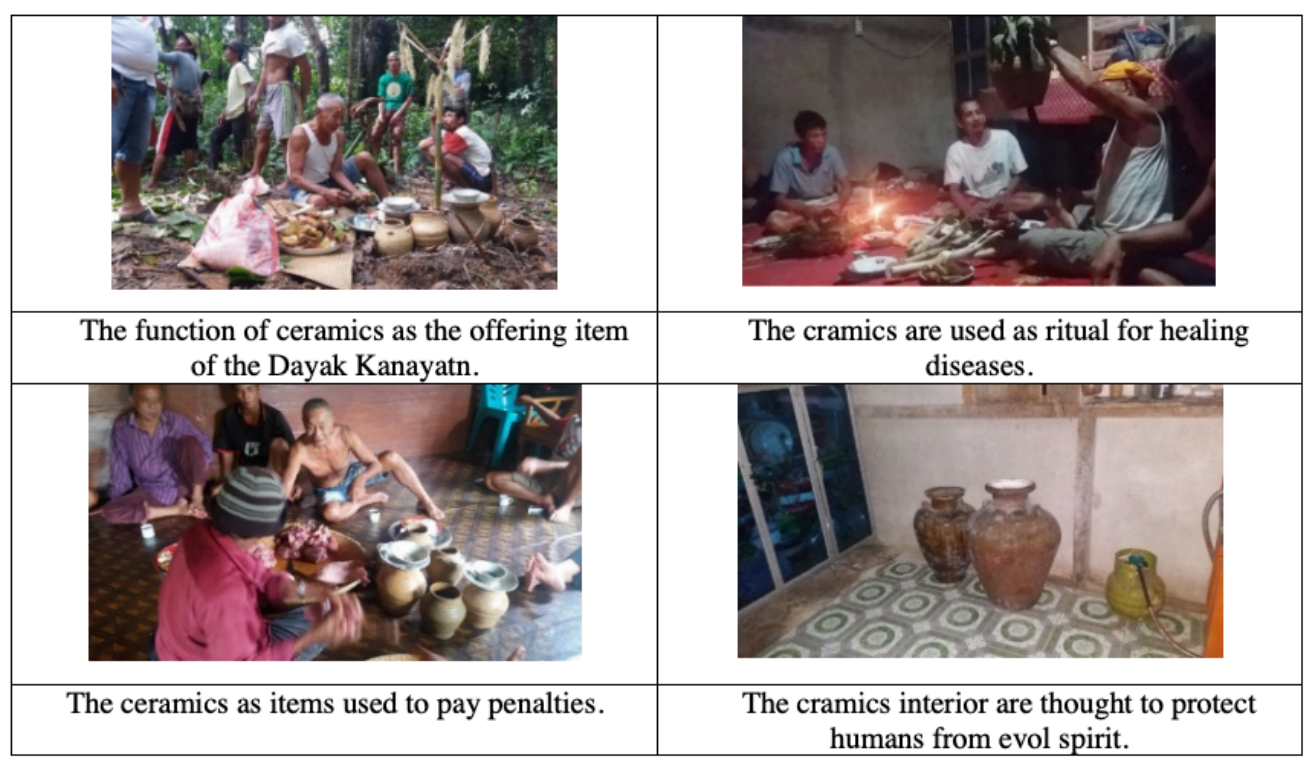

Figure 4. The function of Singkawang ceramics is besed on the perception of the Dayak Kanayatn Source: Iwan Pranoto (April 2017)

of stone made and used as household, and ritual activities based on human beliefs. From the opinion stated, those ceramics are cultural products with the meaning and function as necessities of life and ritual. The ceramics used in their everyday life are manyanyi, siton, boko'o, tatak, karokot, tawakg ba'buh, balangkas, plates of natural landscape motifs, and tetek ijo.

Some Singkawang ceramics products are considered as ancestral inheritance items that do not have a sacred value, but rather indicate a lineage from their ancestors. This is by placing ceramics as home interior displays. Like a kind of ceramic jaya, siam, jampa, manyanyi. In daily life, the community functioning ceramics as items which are considered to have the values of character formation, including the community environment, formal education environment, and family environment. It is in the form of messages that are considered to be able to change deviant deeds in society. The types of ceramics are manyanyi, tajau, siam, jampa, karokot, jaya, siton, ijo, and balangkas.

The function of ceramics in enforcing regulations also carried out by the Dayak Kanayatn community, by using Singkawang ceramics as a fine, so it is obligatory for ceramics owners to redeem it with money, or other valuables. As stated by (Iskandar 2004: 131) that there had been an ethnic war between Madura and Dayak in 1968, and later reconciled by several community leaders and the government one of them was implementing customary law. From the opinion stated, those ceramics are often used as goods to pay customary law fines. Customary law activities are carried out to achieve peace and justice. The types of ceramics that can be used for punishment activities are boko'o, siam, jampa, tajau, balangkas, and tetek ijo. The cultural function of Singkawang ceramics for the Dayak Kanayatn community includes natural signs in the form of shamanism activities, to expel evil spirits when opening huma /field. As stated by (Putra 2013: 160) that the Dayak community has a belief in the form of closeness to nature, so there is a ritual that has a sacred element. From the opinion expressed that Dayak Kanayatn community have a closeness with nature, so that making ceramics is considered as a medium to ward off evil spirits in certain activities, by giving offerings on boko'o, tatak, taboo, and plain bowls.

The activities carried out by the people in this area are related to their ancestral belief system in the form of rituals for jubata. It was made as an offering item to be accepted by his ancestors, various types of traditional ritual sites performed by the Dayak Kanayatn community in this area, including large trees, rivers, rocks, and statues of pantak. As stated by (Andrianus 2016: 139) that the pantak statue is a symbol of the ancestors of Dayak Kanayatn ancestors who have a position in an area. From the opinion expressed that there is a belief system in the Dayak Kanayatn community by performing rituals in places that are considered sacred, by offering ceramics as a connecting item and a sign of request refusing evil forces that are considered to be able to disrupt the lives of the local community, namely, boko'o, plates with plant motifs, and plain bowls. Here is a picture of the ceramics function based on public perception.

From the presentation of the previous picture that the perception that developed in the Dayak Kanayatn community in Antan Rayan, with the view of cultural elements that developed in the community. Every action taken by the community in the functioning of ceramics is based on thought and influence. That does not make a problem in the development of Singkawang ceramics, and can still be accepted as local cultural by bringing up the values that 
develop in the community.

\section{CONCLUSION}

Based on the results of discussions, it can be concluded based on the objectives of the study that ceramic Singkawang have various types of shapes, ranging from size, variant, color, and decoration that have aesthetic value. Singkawang Ceramics owned by the Dayak Kanayatn community have a smooth, simple, and magical surface. It is not separated from the development of people's perception of ceramic Singkawang that can have an impact on the social life of Dayak Kanayatn people as ceramics owners. The perception of the Dayak Kanayatn has an impact on the environment, especially in the functioning of ceramics in everyday life, storing household furniture, and ritual worship activities to ancestors. Thus, Singkawang ceramics have values in the form of social messages, functions of life interests, functions as payment items for customary fines, and functions of ceramics as sacred goods.

\section{REFERENCES}

Adhyatman, S. Ridho, A. 1984. Tempayan di Indonesia. Jakarta: Agung Offset

Andrianus. Sri Iswidayati. Triyanto. Patung Pantak Dayak Kanayatn Kajian Fungsi dan Perubahan Sosial Budaya. UNNES. Catharsis. Volume 5 Nomor 2. 20 Desember 2016

Arimbawa, I Made Gede. 2011. "Basis Perkembangan Pada Produk Keramik Pada Era Pasar Global”. Denpasar: Jurnal Mudra Volume 26 Nomor 2. Juli 2011.

Damayanti, Risca. Triyanto. Muh Ibnan Syahrif. 2016. Masjid Jami’ Piti Muhammad Cheng Hoo Purbalingga: Refleksi Akulturasi Budaya Pada Masyarakat Purbalingga. UNNES. Catharsis. Volume 5 Nomor 2. 20 Desember 2016

Dodo. Sri Iswidayati. Tjeptjep Rohendi Rohidi. 2016. Fungsi dan Makna Bide Dalam Kehidupan Masyarakat Dayak di Kabupaten Landak Kalimantan Barat. UNNES. Catharsis. Volume 5 Nomor 2. 20 Desember 2016

Iskandar, Dadan. 2004. Identitas Budaya Dalam Komunikasi Antar Budaya:Kasus Etnik Madura dan Etnik Dayak. Jurnal Masyarakat dan Budaya. Volume 6 Nomor 2, 2014. Koentjaraningrat. 1986. Pengantar Ilmu Antropologi, Jakarta: Aksara Baru

Laksana, Km Prayudi Indra. I Ketut Sudita. Jajang Surjana. 2013. Seni krerajinan Batu Apung di Desa Bulian Kecamatan Kubu Tambahan Kabupaten Buleleng. Jurnal e-Jurnal Universitas Pendidikan Ganesa. Volume 10. Tahun 2013.
Mulyana, Deddy. 2010. Ilmu Komunikasi. Bandung. Rosda

Murni, Endri Sintiana. Tjeptjep Rohendi Rohidi. Muh Ibnan Syahrif. 2016. "Topeng Seni Barongan di Kendayakan Tegal:Ekspresi Simbolik Budaya Masyarakat Pesisiran”. UNNES. Catharsis. Volume 5 Nomor 2. 20 Desember 2016

Ocvirk. O. 1992. Art Fundamentals: Theory and Partice. Boston: Library of Congress Cataloging in Publiscation Data.

Pawistana. I Kadek, dkk. 2014. "Kerajinan Perak di Desa Bakung, Kecamatan Sukasada, Kabupaten Buleleng". e-Journal Universitas Pendidikan Ganesha Jurusan Pendidikan Seni Rupa (Volume X Tahun 2014).

Putra. R Masri Sareb. 2013. "Berladang dan Kearifan Lokal Manusia Dayak". Jurnal Humaniora Volume 1.Nomor 2. September 2013.

Rahmawati, S. 2011. Kaolin Dalam Industri. Bandung: ITB

Regar, Philep M. Evelin Kawung. Joanne P.M Tangkudung. 2014. Pola Komunikasi Antar Budaya dan Identitas Etnik Sangihe-Talau-d-Sitaro (Studi Pada Masyarakat Etnik Sanger-Tahuna-Sitaro Pada Kota Manado). Jurnal Acta Diurna. Volume 3. Nomor 4. Tahun 2014.

Rohidi, Tjeptjep Rohendi. 2011. Metodologi Penelitian Seni. Semarang: Cipta Prima Nusantara.

2014. Pengembangan Media Pembelajaran Seni Budaya Berbasis Kearifan Lokal (Wayang Sebagai Sumber Gagasan). Jurnal Imajinasi. Vol 8 Nomor 1. Januari 2014

Suryani, Wahidah. 2013. "Komunikasi Antar Budaya: Berbagai Budaya Berbagai Makna”. Jurnal Farabi Vol 10 no 1 Juni 2013.

Syuhendri. 2008. "Tradisi sebagai wadak ketahanan budaya: sebuah kritik kapitalisme terhadap budaya pasar". Resital vol 9 no 1 juni 2008:10-18.

Triyanto. 2014. "Pendidikan Seni Berbasis Budaya". Jurnal Imajinasi. Volume 8 Nomor 1. Januari 2014

2015. "Perkeramikan Mayong Lor Jepara: Hasil Enkulturasi Dalam Komunitas Perajin. Jurnal Imajinasi. Volume IX, Nomor 1. Januari 2015 
. 2016. Paradikma Humanistik dalam Pendidikan

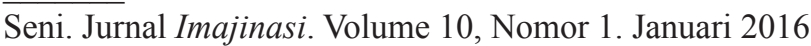

Wastap. Jaeni B. 2010. "Dari Filsafat Keindahan Menuju Komunikasi Seni Pertunjukan”. Jurnal Acta Diurna. Volume 6 No 1, 2010

Wasudewa, Gede, dkk. 2014. "Kerajinan Sandal Berbahan Dasar Daun Lontar di Perusahaan Adi Karya Desa Buna, Kecamatan Blahbatuh Kabupaten Gianyar". e-Journal Universitas Pendidikan Ganesha Jurusan Pendidikan Seni Rupa (Volume X Tahun 2014 hal:2). 